\title{
DEVELOPMENT AND VALIDATION OF HIGH PERFORMANCE LIQUID CHROMATOGRAPHY (HPLC) METHOD FOR CANDESARTAN CILEXETIL IN PURE AND FORMULATION PRODUCTS
}

\author{
Vishnu Vardhan D, Venkateswar $K^{1}$ and Srinivas Nayak A $^{*}$ \\ *University College of Pharmaceutical Sciences, Satavahana University, Karimnagar-505001, \\ Telangana, India. \\ ${ }^{1} \mathrm{CMR}$ engineering college, Hyderabad, Telangana, India
}

\begin{abstract}
*Corresponding Author Email: vishnumsc06@yahoo.co.in
\section{ABSTRACT}

A simple and sensitive determination of candesartan cilexetil in pure and formulation products was done by high performance liquid chromatographic method. The present method consists of protein precipitation, extraction of analytes from samples into acetonitrile and separation using reversed-phase $C_{18}$ column. Losartan potassium was used as an internal standard and the eluent was monitored by UV detector at $252 \mathrm{~nm}$. The mobile phase used was 62:38 ratio of $20 \mathrm{mM}$ phosphate buffer $\mathrm{pH}$ adjusted to 4.0 with OPA and acetonitrile at a flow rate of $1 \mathrm{~mL} \mathrm{~min}^{-1}$. The retention times for drug and internal standard were found to be 3.8 and 7.0 minutes respectively. The intraday and inter-day coefficient of variation and percent error values of assay method were less than $5 \%$ and mean recovery was more than $98 \%$ for each analyte in both pure and formulation products and the method was found to be precise, accurate and specific during study. The method was successfully developed and validated in pure and formulation products, also applied for pharmacokinetic studies.
\end{abstract}

\section{KEY WORDS}

candesartan cilexetil, high performance liquid chromatography, UV detetor, assay, precision.

\section{INTRODUCTION:}

Candesartan cilexetil (CC), is an ester prodrug of candesartan, a non-peptide angiotensin II type 1 (AT1) receptor antagonist used in the treatment of hypertension and heart failure. Candesartan cilexetil is rapidly and completely bioactivated by ester hydrolysis during absorption from gastro intestinal tract to candesartan (Sever, 1997). The major drawback in the therapeutic application and efficacy of candesartan cilexetil as an oral dosage form is its very low aqueous solubility and first-pass metabolism. Low solubility of CC across the physiological $\mathrm{pH}$ range is reported to result in incomplete absorption from the gastrointestinal (GI) tract. Based on its solubility across physiologically relevant $\mathrm{pH}$ conditions and absorption characteristics, candesartan cilexetil is classified in the Biopharmaceutics Classification System (BCS) as a class II drug. Hence there is a need to develop a validated method for the analysis of S(-)-Candesartan cilexetil from API and marketed formulations.

Single analytical approaches are available for the related substances of candesartan cilexetil in tablet formulations and drug substances.[1] A method for the isolation of degradation products is also available.[2] A number of assay methods for determination of candesartan cilexetil in pharmaceutical formulations and human plasma are also available.[픅] A number of assay methods for determination of candesartan cilexetil in combination pharmaceutical formulations are also available.[요의 However; all the above- 
mentioned methods are orientated to the determination of the active pharmaceutical compound. Nowadays, the pharmaceutical industry is forced to assess a strict control of impurities when manufacturing drug substances and drug products. Determination of impurities during the development of separation methods is one of the main and difficult tasks for pharmaceutical analysts, especially if increasingly impurities of closely related structure require determination. Methods are available for the estimation of candesartan cilexetil with spectrofluorimetry.[10]. To the best of our knowledge, this is the first report to develop and validate a simple and efficient HPLC method using Phenomenex Lux Cellulose-4 column as chiral stationary phase and UV detection for the analysis of Candesartan cilexetil from API and marketed formulations.

\section{MATERIALS:}

\subsection{Materials}

Candesartan cilexetil and Losartan potassium pure samples were donated respectively by Aurabindo pharmaceuticals, Hyderabad, India. Acetonitrile, methanol (HPLC) and potassium dihydrogen orthophosphate, ortho phosphoric acid (GR) and sodium hydroxide were purchased from Merck, Mumbai, India. Double distilled water was used during the entire HPLC procedure.

\section{Chromatographic conditions}

Analysis of samples was performed using HPLC. The HPLC system (Shimadzu, Kyoto, Japan) consisted of two LC-20AD Prominence liquid chromatography pumps, LC-20AD UV detector, CTO-20AC Prominence column oven with Lab solutions (LC solutions) software. The analytical column used was Onyx monolithic $\mathrm{C}_{18}$ column (Phenomenex, $100 \mathrm{~mm}^{2} 4.6 \mathrm{~mm}$ i.d, particle size $5 \mu$ ) at $25^{\circ} \mathrm{C}$ temperature. The mobile phase used was $62: 38$ ratio of $20 \mathrm{mM}$ phosphate buffer $\mathrm{pH}$ adjusted to 4.0 with OPA and acetonitrile at a flow rate of $1 \mathrm{~mL} \mathrm{~min} \mathrm{~m}^{-1}$ and detection was carried out at $254 \mathrm{~nm}$. The retention times for drug and internal standard were found to be 3.8 and 7.0 minutes respectively. The injection volume was $20 \mu \mathrm{L}$ and detector sensitivity was set to 0.0001 AUFS.

\section{Standard solution preparation:}

Stock solutions of Candesartan cilexetil at a concentration $0.1 \mathrm{mg} / \mathrm{mL}$ were prepared by dissolving accurately weighed respective standard drugs in HPLC grade methanol.

\section{Sample preparation:}

Twenty tablets of Candesartan cilexetil (ATACAND ${ }^{\circ}$ ) were weighed and then finely powdered. An accurately weighed portion of the powder, equivalent to about $8 \mathrm{mg}$ of Candesartan cilexetil, was transferred to a 100 $\mathrm{ml}$ volumetric flask and $40 \mathrm{ml}$ of Methanol was added. Then the volumetric flask was shaken mechanically for 5 minutes, sonicated for $10 \mathrm{~min}$, and diluted to volume with Methanol. $1 \mathrm{ml}$ of this solution was transferred to a $100-\mathrm{ml}$ volumetric flask and diluted to volume with Methanol. A portion of this solution was filtered through syringe-driven PVDF hydrophilic membrane filter of pore size $0.22 \mu \mathrm{m}$ and which was used as sample.

\section{Method validation:}

According to the $\mathrm{ICH}$ guidelines, the developed method was validated to assure the reliability of the results of the analysis for different parameters like system suitability, linearity, limit of detection (LOD), limit of quantification (LOQ), accuracy, precision and robustness [12].

\section{System suitability}

The system suitability was determined by calculating retention factor, separation factor and tailing factor of drug and IS peaks resulted for the HPLC method analysis of Candesartan cilexetil. The retention factor $(k)$ was calculated as $k=\left(t_{R}-t_{M}\right) / t_{M}$ where, $t_{R}$ refer to the retention time of the analyte and $t_{M}$ refer to the elution time of the non-retained components. The separation factor $(\alpha)$ was calculated as the ratio of retention factors, $\alpha=k 2 / k 1$. The resolution factor (Rs) was calculated as $\mathrm{Rs}=2(\mathrm{t} 2-\mathrm{t} 1) /(\mathrm{w} 1+\mathrm{w} 2)$ where, $\mathrm{t} 1$, $\mathrm{t} 2$ refer to the retention time of the first and second enantiomers; w1 and w2 are the peak widths for the first and second eluting enantiomers, respectively. Tailing factor $(T)$ was calculated as $T=W_{0.05} / 2 f$ where, $W_{0.05}$ is the width of peak at $5 \%$ height from base line and $f$ is the distance from peak maximum to the leading edge of the peak.

\section{Linearity}

Linearity was assessed by plotting calibration curve of $C$ C. For this, five different concentration solutions of CC like $0.1,0.25,0.5,1,2.5$ and $5 \mu \mathrm{g} / \mathrm{mL}$ were prepared from the stock solution using Methanol as diluent. The calibration curve was obtained by plotting peak area versus concentration, using the least squares method. Linearity was checked for three consecutive days in the same concentration range from the same stock 
solution. The percentage relative standard deviation (RSD) of the regression coefficient was calculated. LOD

LOD was calculated using the following formula;

$$
L O D=3.3 \sigma / S
$$

where $\sigma$ is the standard deviation of the response and $S$ is the slope of the calibration curve.

LOQ

LOQ was calculated using the following formula;

$$
L O Q=10 \sigma / S
$$

where $\sigma$ is the standard deviation of the response and $S$ is the slope of the calibration curve.

\section{Accuracy}

Accuracy was determined by the standard addition method. Previously analyzed marketed samples of CC $(1 \mu \mathrm{g} / \mathrm{mL})$ were added up with 50,100 , and $150 \%$ of standard CC separately. Each sample was prepared in triplicate $(n=3)$ and all the samples were analyzed by the proposed method. Recovery (\%), RSD (\%), and standard error (SE) were calculated.

\section{Precision}

Precise method should have the reproducibility and was determined by measuring repeatability (intra-day) and intermediate precision (inter-day precision) of peak areas of the drug. In order, to determine the repeatability of the method, three different concentration solutions of CC like 15, 2450 and 4500 $\mathrm{ng} / \mathrm{mL}$ were prepared in triplicate $(\mathrm{n}=3)$ and were analyzed by the proposed method. The intermediate precision was determined by analyzing six samples $(\mathrm{n}=6)$ of $50 \mathrm{ng} / \mathrm{ml} \mathrm{CC}$ solution on three consecutive days.

\section{Robustness}

To determine robustness of the method, experimental conditions were purposely altered, and after analysis changes in retention time of the $\mathrm{CC}$ was observed. The effect of change in flow rate on retention time of $\mathrm{CC}$ was studied by changing the mobile phase flow rate to 0.9 $\mathrm{mL} / \mathrm{min}$ as well as $1.1 \mathrm{~mL} / \mathrm{min}$ instead of $1 \mathrm{~mL} / \mathrm{min}$, while the other chromatographic conditions were held constant. The effect of temperature on retention time of the enantiomer was studied at $38^{\circ} \mathrm{C}$ and $42^{\circ} \mathrm{C}$ instead of $40^{\circ} \mathrm{C}$ while the other mobile phase components were held constant, as stated in chromatographic condition section.

\section{Results and Discussion:}

Various solvent mixtures were tried for the analysis of Candesartan cilexetil with good resolution. However, 62:38 ratio of $20 \mathrm{mM}$ phosphate buffer $\mathrm{pH}$ adjusted to 4.0 with OPA and acetonitrile was given well-resolved sharp peaks with very good symmetry. The flow rate was set depending on the resolution factor, peak shape, tailing factor and time required for the analysis. Candesartan cilexetil (API) and Candesartan cilexetil tablet formulation (ATACAND ${ }^{\circ}$ ) were analyzed by this method and their chromatograms were shown in Figure 1, 2 and 3, respectively. The retention time of standard CC and IS were found as 3.8 and 7.0 minutes respectively. As the retention time of standard enantiomers were comparable to that of the Candesartan cilexetil API and ATACAND ${ }^{\circ}$, the present method can be used for the analysis of Candesartan cilexetil from various marketed formulations.

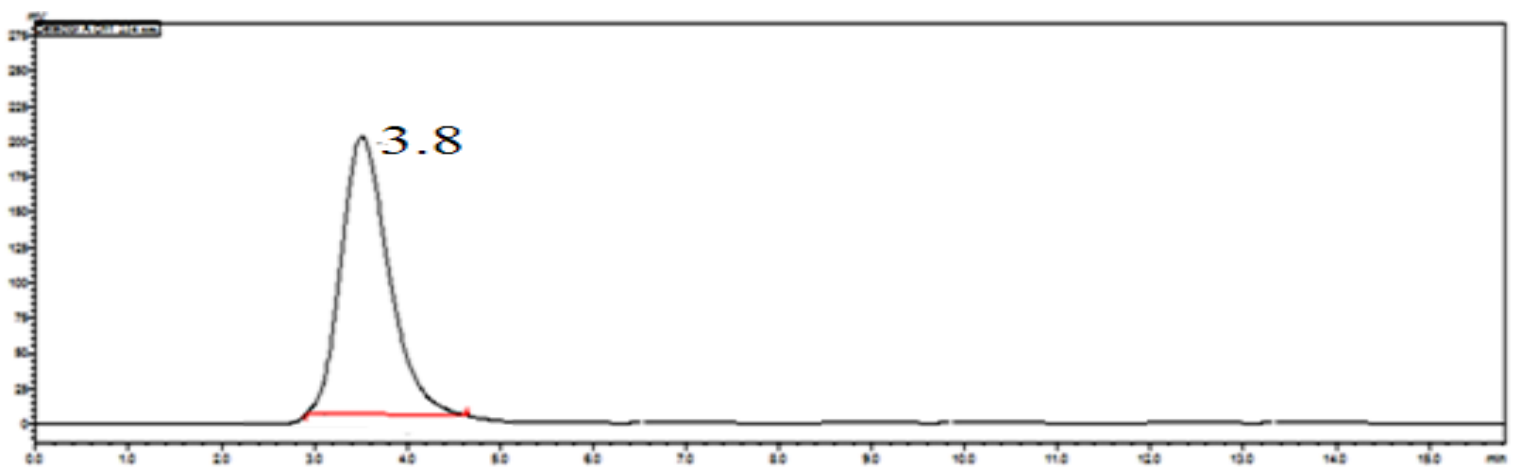

Figure 1. Chromatogram of Candesartan cilexetil $(1000 \mathrm{ng} / \mathrm{mL})$ 


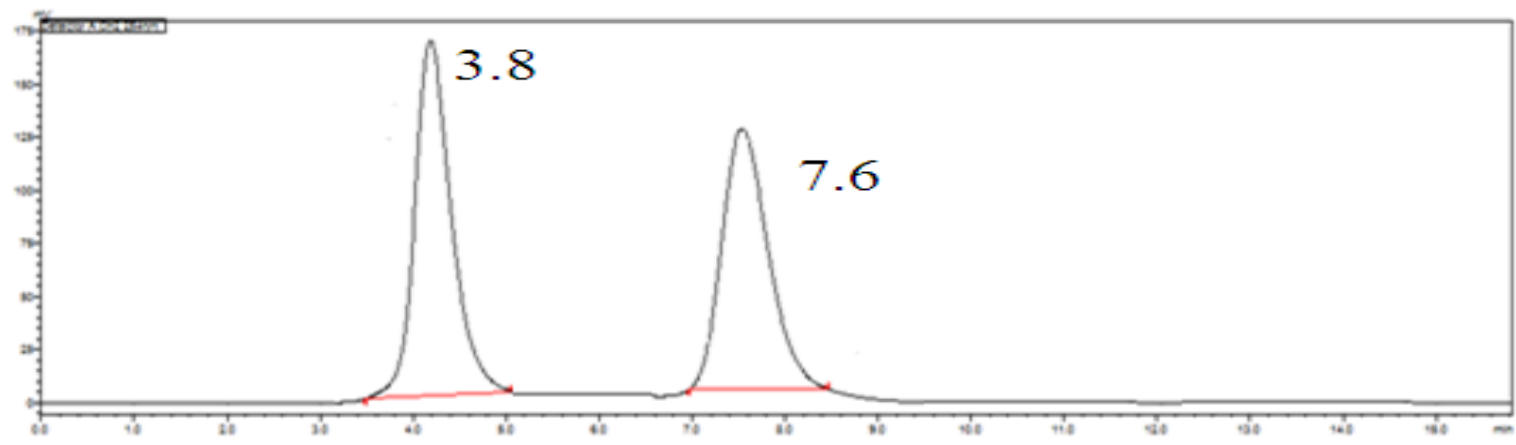

Figure 2. Chromatogram of drug and IS $(1000 \mathrm{ng} / \mathrm{mL})$

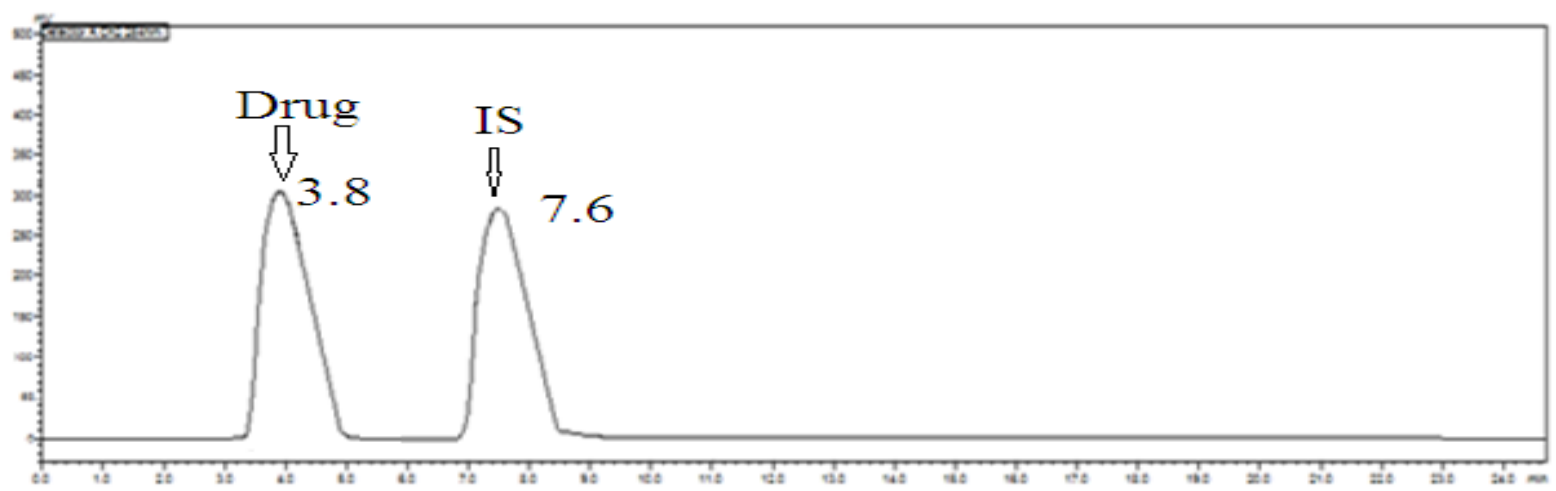

Figure 3. Chromatogram of ATACAND and IS $(1000 \mathrm{ng} / \mathrm{mL})$

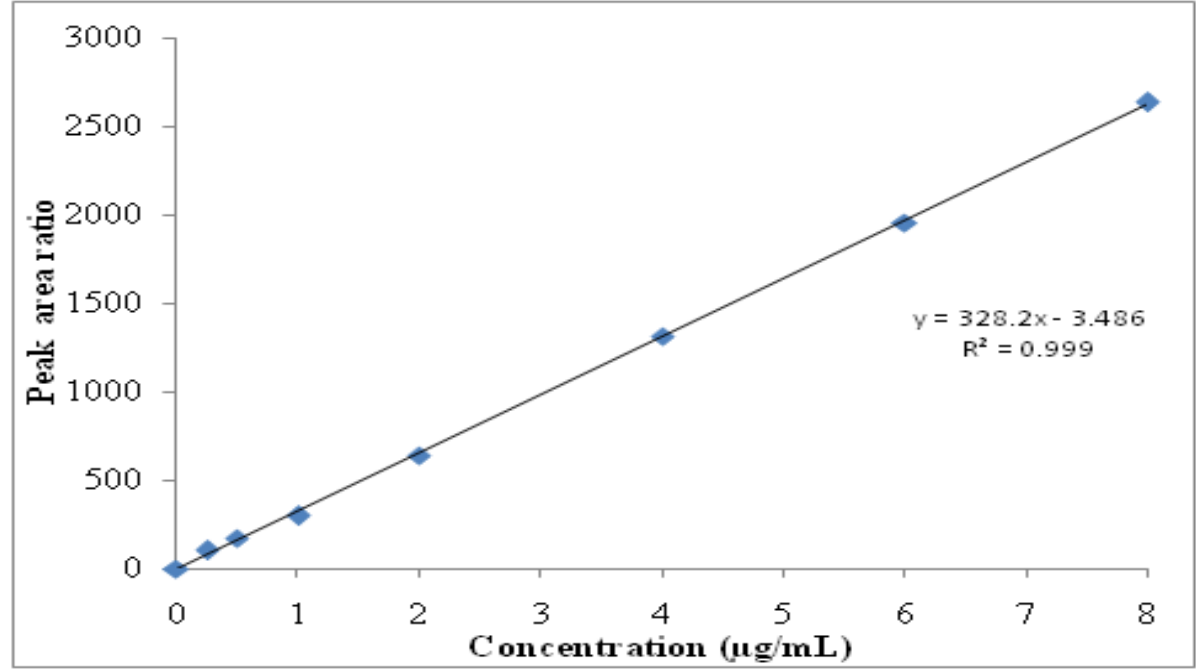

Figure 4: Standard graph of Candesartan cilexetil

\section{Validation of the method}

System suitability parameters were evaluated. The separation factor and resolution factor of enantiomers of the Candesartan cilexetil and IS were found as 1.55 and 1.82 , respectively. These values were greater than the minimum values mentioned in $\mathrm{ICH}$ guidelines and hence the method proved to provide good resolution of enantiomers of $\mathrm{c}$ Candesartan cilexetil. As per $\mathrm{ICH}$ guidelines, the tailing factor should be less than 2 and the present method has shown tailing factors of drug and IS as 0.33 and 0.42 , respectively. Hence the method offers well resolved sharp peaks for the Candesartan cilexetil with good symmetry. The retention factor is often used to describe the migration rate of an analyte on a column and as per $\mathrm{ICH}$ guidelines it should be between 1 and 10 . The method has given retention factors of drug and IS as 1.9 and 2.22, respectively and was found to be in the limit of ICH guidelines. Hence the 
both drugs will take less time for elution and the analysis will complete in short duration of time. All the parameters were proved that the chromatographic system used was suitable for the analysis of Candesartan cilexetil from API and formulations.

\section{Linearity}

The calibration curve of CC was plotted using peak area ratio vs. concentration and was shown in Figure 4 . The experiment was repeated for three times $(n=3)$ and the relative standard deviation (RSD) was calculated for regression coefficient. The method has shown good linearity for $\mathrm{CC}\left(\mathrm{r}^{2}=0.9997\right)$ in the concentration range of $0.25-8 \mu \mathrm{g} / \mathrm{mL}$. As the \%RSD of regression coefficient was found to be very less $(<2 \%)$, which is within in the limits of ICH guidelines and the methods linearity was proved to be reproducible.

\section{LOD and LOQ}

The LOD and $L O Q$ values of CC found by this method. The low values of LOD and LOQ indicates that the method can be used for detection and quantification of CC over a very wide range of concentrations.

\section{Accuracy}

Accuracy of the method was ascertained by recovery method. For this purpose previously analyzed ATACAND test solutions of concentration $1 \mu \mathrm{g} / \mathrm{mL}$ were added up with $50,100,150 \%$ of standard drug, separately. The samples were prepared in triplicate $(n=3)$ and analysis was carried out by the proposed method. The \% recoveries along with relative standard deviation (RSD) and standard error (SE) values were shown in Table 1. The overall average \% recovery of CC was found as 99.05 $\%$ with very less standard deviation and negligible standard error, which proves the developed method as accurate.

\section{Precision}

To determine intra-day precision, three different concentrations of $C C(15,2450$ and $4500 \mathrm{ng} / \mathrm{mL})$ were prepared in triplicate $(n=3)$ and analyzed at specific time intervals in the same day. The Coefficient of Variance (\%CV) was calculated for all the samples and the values along with RSD and SE were given in Table 2. All the three different concentration samples of CC were shown insignificant RSD and SE in their Coefficient of Variance, which indicates that the method has good repeatability.

For inter-day precision analysis, six samples of CC, 15 $\mathrm{ng} / \mathrm{mL}$ concentration solution $(\mathrm{n}=6)$, were prepared and analyzed for three consecutive days. Average \% Coefficient of Variance of CC on each day was calculated and given along with their RSD and SE in Table 1. The RSD and SE of \% CV of CC for all the three consecutive days was found to be less than $2 \%$, which is the limit as per ICH guidelines and hence the method proved to be precise.

\section{Robustness}

Chromatographic conditions of the method were altered briefly and analysis of CC was performed for three times $(n=3)$. Changes in retention time were recorded and the \%RSD of retention time of CC respective to change in each parameter was shown in Table 3. As the \%RSD of retention time of CC for each change in parameters was less than $2 \%$, which is the limit as per ICH guidelines and hence the method proved to be robust. Hence slight changes in temperature and mobile phase flow rate will not affect the method in analysis of Candesartan cilexetil from API and formulations.

Table 1: Intra-day and inter-day precision and accuracy data for assay of CC ( $n=6)$

\begin{tabular}{|c|c|c|c|c|c|c|}
\hline \multirow{2}{*}{$\begin{array}{l}\text { Added conc } \\
\left.\text { (ng mL } \mathrm{mL}^{-1}\right)\end{array}$} & \multicolumn{2}{|c|}{$\begin{array}{l}\text { Calculated conc } \\
\text { (ng mL }{ }^{-1} \text { ) }\end{array}$} & \multicolumn{2}{|l|}{$\% \mathrm{CV}$} & \multicolumn{2}{|c|}{$\%$ Relative error } \\
\hline & Intra day & Inter day & Intra day & Inter day & Intra day & Inter day \\
\hline 15 & 14.88 & 14.90 & 14.83 & 14.88 & 0.19 & -1.5 \\
\hline 2450 & 2448.8 & 2443.2 & 5.2 & 4.3 & -2.3 & -1.0 \\
\hline 4500 & 4502.6 & 4497.7 & 4.4 & 2.9 & 0.9 & -1.3 \\
\hline
\end{tabular}


Table 2: Recovery and accuracy of the proposed method

\begin{tabular}{|c|c|c|c|c|c|c|c|}
\hline \multirow{2}{*}{$\begin{array}{l}\text { Conc } \\
\left(\mathrm{ng} \mathrm{mL^{-1 }}\right)\end{array}$} & \multicolumn{4}{|c|}{ Absolute recovery } & \multicolumn{3}{|c|}{ Accuracy (\%) } \\
\hline & $\begin{array}{l}\text { Conc (ng mL } L^{-1} \text { ) } \\
(\text { Mean } \pm S D)\end{array}$ & $\begin{array}{l}\text { Mean (\%) } \pm \text { S.D } \\
(n=5)\end{array}$ & $\begin{array}{l}\text { Range } \\
\text { (Min-Max) }\end{array}$ & $\% \mathrm{CV}$ & $\begin{array}{l}\text { Mean } \pm \text { SD } \\
(n=5)\end{array}$ & $\begin{array}{l}\text { Range } \\
\text { (Min-Max) }\end{array}$ & $\% \mathrm{CV}$ \\
\hline 15 & $14.99 \pm 0.05$ & $98.5 \pm 1.7$ & $95.1-99.2$ & 2.2 & $96.9 \pm 1.9$ & $93.6-99.7$ & 3.6 \\
\hline 2450 & $2448.4 \pm 36.8$ & $99.1 \pm 2.6$ & $93.6-99.6$ & 2.6 & $95.1 \pm 3.0$ & $93.9-97.9$ & 2.03 \\
\hline 4500 & $4495.7 \pm 121.4$ & $98.9 \pm 2.3$ & $93.2-99.8$ & 2.82 & $94.6 \pm 1.9$ & $91.8-99.7$ & 2.4 \\
\hline
\end{tabular}

Table 3: Stability study results of the proposed method

\begin{tabular}{|c|c|c|c|c|c|c|}
\hline \multirow[t]{2}{*}{ Stability } & \multirow{2}{*}{$\begin{array}{l}\text { Spiked conc } \\
\left(\mathrm{ng} \mathrm{mL} \mathrm{L}^{-1}\right)\end{array}$} & \multicolumn{2}{|c|}{$\begin{array}{l}\text { Calculated comparison sample } \\
\text { concentration }\left(\mathrm{ng} \mathrm{mL}^{-1}\right)^{d}\end{array}$} & \multicolumn{2}{|c|}{$\begin{array}{l}\text { Calculated stability sample } \\
\text { concentration }\left(\mathrm{ng} \mathrm{mL}^{-1}\right)^{d}\end{array}$} & \multirow[t]{2}{*}{ Avg \% } \\
\hline & & Mean \pm SD & $\% \mathrm{CV}$ & Mean \pm SD & $\% \mathrm{CV}$ & \\
\hline \multirow{3}{*}{ Bench top ${ }^{a}$} & 15 & $14.89 \pm 0.09$ & 3.8 & $14.86 \pm 0.15$ & 8.5 & 98 \\
\hline & 2450 & $2448.5 \pm 22.8$ & 2.5 & $2447.3 \pm 32.5$ & 3.2 & 98.5 \\
\hline & 4500 & $4492.6 \pm 72.6$ & 2.1 & $4495.8 \pm 92$ & 1.3 & 100 \\
\hline \multirow{3}{*}{ Freeze and thaw ${ }^{b}$} & 15 & $14.94 \pm 0.1$ & 5.8 & $14.82 \pm 0.2$ & 8.4 & 96.4 \\
\hline & 2450 & $2448.6 \pm 75.2$ & 2.7 & $2449.8 \pm 46.2$ & 3.1 & 98.9 \\
\hline & 4500 & $4503.7 \pm 104.4$ & 1.9 & $4498.2 \pm 121.3$ & 1.5 & 100 \\
\hline \multirow{3}{*}{ Long term ${ }^{c}$} & 15 & $14.88 \pm 0.1$ & 4.2 & $14.79 \pm 0.14$ & 5.2 & 97 \\
\hline & 2450 & $2448.5 \pm 72.6$ & 2.4 & $2445.3 \pm 55.6$ & 3.0 & 99 \\
\hline & 4500 & $4451.6 \pm 113.4$ & 2.6 & $4448.2 \pm 88.2$ & 1.7 & 99.5 \\
\hline
\end{tabular}

\section{CONCLUSION:}

The present work was intended for the analysis of Candesartan cilexetil from API and formulations, both qualitatively and quantitatively. For this purpose, a simple and rapid HPLC method was developed and validated. Statistical analysis results of the method validation revealed that the method has high accuracy with a good precision. Hence the method is reliable and convenient for routine quality control and stability assays of $\mathrm{CC}$ in both $\mathrm{API}$ and marketed tablet formulations.

\section{REFERENCES:}

1. Sever P. Candesartan cilexetil: a new, long-acting, effective angiotensin II type 1 receptor blocker. J Hum Hypertens. 1997; 11 (2): 91-95.

2. Subba Rao DV, Radhakrishnanand P, Suryanarayana MV, Himabindu V. A stability-indicating LC method for candesartan cilexetil. Chromatographia. 2007; 66:499507.

3. Mohan A, Shanmugavel S, Goyal A, Venkataraman BR, Saravanan D. Identification, isolation, and characterization of five potential degradation impurities in candesartan cilexetil tablets. Chromatographia. 2009; 69:403-603.

4. Akula G, Saikrishna K, Bhupathi S, Ramesh Kumar R, Santhosh Kumar K. RP-HPLC method development and validation of candesartan cilexetil in bulk and their pharmaceutical dosage forms. Int J Pharm Sci Res. 2010; 1:191-6.

5. Kamalakkannan V, Puratchikody V, Masilamani K, Saraswathy T. Analytical method development and validation for Candesartan Cilexetil as bulk drug and in pharmaceutical dosage forms by HPLC. Der Pharmacia Lett. 2011; 3:286-96.

6. Peepliwal AK, Bonde CG, Mohanraj K. Bioanalytical method development and its validation for determination of candesartan cilexetil by high performance liquid chromatography with UV Detection. Acta Pharm Sci. 2010; 52:247-53.

7. Erk N. Simultaneous Analysis of Candesartan Cilexetil and Hydrochlorothiazide in Human Plasma and Dosage Forms Using HPLC with a Photodiode Array Detector. JLCRT. 2003; 26:2581-91.

8. Stenhoff H, Lagerstrom PO, Andersen C. Determination of candesartan cilexetil, candesartan and a metabolite in human plasma and urine by liquid chromatography and fluorimetric detection. J Chromatogr B Analyt Technol Biomed Life Sci. 1999; 731:411-7.

9. Qutab SS, Razzaq SN, Ashfaq M, Shuja ZA, Khan IU. Simple and sensitive LC-UV method for simultaneous analysis of hydrochlorothiazide and candesartan cilexetil in pharmaceutical formulations. Acta Chromatogr. 2007; 19:119-29.

10. Balamuralikrishna K, Syamasundar B. Development, and validation of high performance liquid chromatographic method for the simultaneous estimation of candesartan 
cilexetil and hydrochlorothiazide in combined tablet dosage form. Der Pharma Chemica. 2010; 2:231-7.

11. Alhaj Sakur A, Hanan FA. Determination of candesartan cilexetil in tablets by spectrofluorimetry. Int J Pharm Sci Rev Res. 2010; 4:60-3.
12. Guidance for Industry: Bioanalytical Method Validation, US Department of Health and Human Services, Food and Drug Administration, Center for Drug Evaluation and Research, Rockville, MD, 2001. 